\title{
THE CONCEPT OF VULNERABILITY WITHIN RESEARCH ETHICS AND HEALTH POLICIES ON RARE DISEASES ${ }^{1}$
}

\begin{abstract}
Rare diseases have held a special status within health policy of the European Union (EU) since the 1990s. According to key EU legal documents on this issue, patients who suffer from a rare disease are entitled to the same good quality care as others. Due to the "low prevalence" of each rare disease and simultaneously the large total number of patients affected by them - between 27 and 36 million people in the EU - individuals who belong to this group are regarded as particularly vulnerable.

Classifying people with rare diseases as vulnerable raises ethical issues that have rarely been discussed by scholarship in social sciences and humanities. Drawing on existing literature, I argue that research ethics as well as ethics and politics of public health espouse a negative and labelling understanding of vulnerability. According to this concept of vulnerability some individuals, groups or populations are classified as being subjected to greater harm or hurt than others; thus, they require special support from, for instance, researchers and/or the healthcare system. As a result, such an understanding increases the danger of paternalistic practices and "pathogenic vulnerability" [Mackenzie 2013]. It may also contribute to discrimination, stigmatising and victimising. As I show in this article, health policies tailored to rare diseases often run the risk of increasing "pathogenic vulnerability".
\end{abstract}

Keywords: vulnerability, research ethics, rare diseases, ethnography, health policies

Dr hab., prof. IFiS PAN; e-mail: mrajtar@ifispan.edu.pl; https://orcid.org/0000-0002-3807-1547

1 The article was originally written in Polish and this is its English translation.. 


\section{INTRODUCTION}

This article provides an analysis of a problem rarely discussed in the literature of the humanities and social sciences (especially bioethics, and medical anthropology and sociology), namely the ethical issues related to classifying people who suffer from rare diseases as a so-called vulnerable group ${ }^{2}$. The concept of vulnerability, albeit criticised, occupies a prominent place in philosophy, research ethics and bioethics, social sciences as well as in the ethics and politics of public health. In research ethics and the ethics and politics of public health a negative and labelling understanding of vulnerability prevails. This understanding of vulnerability classifies certain individuals, groups or populations as more susceptible to harm or being hurt than others; as such they require special protection, be it from those conducting the research or, for example, from the healthcare system. Following other researchers, I argue that such an approach not only questions the autonomy of people or groups described as vulnerable, but could also facilitate paternalistic practices [e.g., Mackenzie 2013, Rogers 2013] and "pathogenic vulnerability" [Mackenzie 2013]. It may also encourage discriminating, stigmatising and victimising processes [Goffman 1986, Link, Phelan 2001]. As I show in this paper, these are the dangers entailed by health policies related to rare diseases.

This article is based on the results of studies that have been carried out within three projects in Poland and - comparatively - in Finland and Sweden since 2016 2 .

2 As emphasised by Zygmunt Bauman [2003], among others, the Polish language lacks an appropriate equivalent of the English concept of "vulnerability". According to Bauman, the English word "vulnerability" "suggests sensitivity or being prone to injuries, the lack of, or insufficient protection from, being harmed, overall weakness and susceptibility to being a victim of violent attacks or giving in to ailments" [2003: 45]. Bauman proposes to translate this term as "ranliwość" ("woundability") [Bauman 2003: 45]. In the context of research on natural hazards - where, as I show below, it plays a crucial role - the same term is translated into Polish as "podatnośc" ("susceptibility") or "wrażliwość" ("sensitivity") [Rucińska 2014, Działek, Biernacki 2014]. Translations encountered in the field of ethics and bioethics are "cielesna podatność" ("bodily susceptibility") [Świerkosz 2018] or "podatność na zranienie" ("susceptibility to harm").

3 Research is carried out within two grants; I am the PI in both: (1) "Socio-Cultural Dimensions of Rare Diseases: The Case of LCHAD Deficiency. A Comparative Study of Poland and Finland" (2016-2019, grant funded by The National Science Centre, grant no. 2015/17/B/HS3/00107) and (2) "An Anthropology of Rare Diseases. A Study of the Baltic Sea Region" (2018-2022, grant funded by The National Science Centre, grant no. 2017/26/E/HS3/00291). The third project was conducted at the Helsinki Collegium for Advanced Studies (2018-2019) within the EURIAS Fellowship Programme and the European Commission (Marie-Sklodowska-Curie Action - COFUND Programme - FP7), titled "Food, Biomedical Technologies, and Care. The Case of Rare Metabolic Disorders". I was inspired to write this article while preparing applications for ethics committees in Finland and Sweden as well as by observing the development of healthcare policy in Poland, 
The ethnographic research is being conducted with people suffering from rare diseases, particularly inborn errors of metabolism ${ }^{4}$ as well as with their families, representatives of patient organizations and the medical community. We conduct participant observation in patients' homes, at culinary workshops, Rare Disease Day that is celebrated every year on the last day of February and other events related to rare diseases, such as conferences tailored to the representatives of patient organizations, the medical community as well as to patients and their families. We gather illness narratives [Kleinman 1989] and conduct in-depth interviews with doctors, geneticists, dieticians and representatives of patient organizations in Poland, Finland and Sweden. In addition, we analyse legal documents on rare diseases and orphan drugs as well as pamphlets and other texts addressed to patients and their relatives; we also follow media discourse and discussions on social media platforms for patients and their families.

In our research, we focus on rare metabolic diseases, in particular fatty acid oxidation disorders (FAODs) and organic acid disorders (OADs). Rare metabolic diseases are genetic disorders in the metabolism of proteins, fats and carbohydrates [Ehmke vel Emczyńska-Seliga 2016]. In Poland, Finland and Sweden inborn errors of metabolism have been detected in neonatal screening ${ }^{5}$ for the last 10 years. This, along with the prevalence of these particular diseases in any given country constituted one of the criteria for selecting a comparative study area.

Similarly to other rare diseases [van der Lippe et al. 2017], there are currently no medicines suitable for treating patients suffering from rare metabolic conditions. The very process of "treatment" poses clinical challenges and requires patients to adhere to a lifelong dietary regimen. Many of these patients must avoid fasting in order to prevent dangerous complications, in particular hypoglycaemia and metabolic decompensation which may even be caused by the common cold

specifically the National Plan for Rare Diseases. Due to the highly time-consuming process of obtaining consent from the Ethics Committee in Sweden, research in that country was delayed until January 2020; additionally, the latest Finnish Plan for Rare Diseases lacks the key bio-political "instrument" analysed in this article: the "Passport of care for a patient suffering from a rare disease". Hence, where this article focuses on healthcare policy, I refer primarily to the research material from Poland.

4 The term "inborn errors of metabolism" was coined in 1909 by British doctor and biochemist, Archibald Garrod, to describe "a group of conditions that "apparently result from the failure of some step or other in the series of chemical changes that constitute metabolism"' [Garrod 1963(1909): 13 in: Paul, Brosco 2013: 11].

5 It is worth noting that the pilot phenylketonuria (PKU) screening programme in Poland dates back to 1965 , however, it was not extended to the entire population of newborns until the late 1980s [for newborn screening tests in Poland see, for example, Ołtarzewski 2018]. 
[Ehmke vel Emczyńska-Seliga 2016]. Such a regimen deviates quite significantly from dietary recommendations for "normal" children [Rajtar 2019, see also Chowaniec-Rylke 2018]. Moreover, children and adolescents often experience problems with eating that necessitate tube feeding [Rajtar 2017]. Patients require strict clinical, biochemical and dietary monitoring and depending on the course of the disease may require frequent hospitalization.

This article begins by discussing the concept of vulnerability in research ethics and outlining theoretical approaches to this concept in philosophy and social sciences.

\section{THE CONCEPT OF VULNERABILITY IN RESEARCH ETHICS}

Over the past few decades, the concept of vulnerability has held a central place in bioethics and research ethics. Current debates on this concept were inspired by the first codes of research ethics, in particular "The Belmont Report" (1979) - a document of the American National Commission for the Protection of Human Subjects of Biomedical and Behavioral Research containing a set of basic ethical principles and guidelines which should underlie all biomedical and behavioural studies with research participants [Bracken-Roche et al. 2017, Rogers 2013] ${ }^{6}$. The three principles promoted in the Report - respect for persons, beneficence and justice - were designed to ensure protection for all human subjects. The Report distinguishes "vulnerable participants (...) presumably from nonvulnerable participants" and lists particularly vulnerable groups [Rogers 2013: 64]. Asking why vulnerability is an important issue for bioethics, Ruth Macklin says that the simplest - though not necessarily satisfactory - answer is, "that vulnerable individuals and groups are subject to exploitation, and exploitation is morally wrong" [2003: 472]. However, as ethicists and social researchers admit, the concept of vulnerability lacks a uniform definition and in practice - when we focus on members of groups considered to be vulnerable - its use is either "too broad" or "too narrow" [Bracken-Roche et al. 2017, Honkasalo 2018, Lange et al. 2013, Macklin 2003, Rogers 2013, among others].

As Dearbhail Bracken-Roche and colleagues [2017] emphasise, the same problem is true for international and national recommendations and practises

6 Of course, we cannot forget about the key role of the Nuremberg Code in creating bioethics and research ethics. Although the concept of vulnerability has not been explicitly mentioned there, the Code "has an implicit assumption that all research participants are vulnerable" [Lange et al. 2013: 334, see also 2013: 63-64, Różyńska 2016]. 
concerning research ethics, for example the Declaration of Helsinki [2013] or the aforementioned Belmont Report [1979] $]^{7}$. Both mention the concept and explicitly list "vulnerable subjects", however, they do not provide any definition of the terms, merely listing groups which are more likely to be vulnerable. As philosopher and bioethicist Wendy Rogers observes, it may result from the fact that in bioethics the meaning of vulnerability is considered "self-evident": "the vulnerable are those who are at increased risk of harms, either because they are in hazardous situations or because they have a decreased capacity, for whatever reason, to safeguard their own interests" [Rogers 2013: 63]. Depending on the way recommendations are formulated, groups described in such a way comprise of, for example, "neonates in intensive care", "elderly persons", "persons with limited capacity to provide an informed consent or lack thereof", "persons who have serious, potentially disabling or life-threatening diseases", "very sick persons", "people suffering from multiple chronic conditions", but also "members of communities unfamiliar with modern medical concepts" or "pregnant or breastfeeding women" [Bracken-Roche et al. 2017: 8-10, see also Macklin 2003, Rogers 2013]. Such an approach, described as "labelling" of populations is, as Rogers [2013] and Lange et al. [2013] note, problematic and not very useful in the context of research. Moreover, ethics commitee proposals and recommendations from other bodies tend to provide solutions which focus on issues such as the necessity of obtaining informed consent from research participants. However, such solutions do not quite accomplish the goal; for example, they do not protect the participants form „researchers with conflicts of interests" or from „disfunctional institutions” [Lange et al. 2013: 335]. This is the case for several reasons. First, in no way does such an approach capture the complexity of human vulnerability, "an individual may be vulnerable for more than one reason, and stating that they are vulnerable because they belong to a subpopulation does not capture that fact" [Lange et al. 2013: 335]. Labelling certain populations as vulnerable, "undermines respect for individual autonomy, thereby opening up its own set of potential harms" [Rogers 2013: 70]. Second, this approach could encourage discriminatory, stereotyping and excluding practices. As a result, persons or groups considered to be vulnerable may be excluded from participating in research that would aid the development of adequate and/or safe treatment for them.

7 A comprehensive list of analysed documents and a thorough discussion of methodological issues can be found in Bracken-Roche et al. 2017. The authors emphasise that in the documents they analysed 51 groups were identified as vulnerable, most frequently "children, minors or young people", "prisoners", "persons with mental health issues", "patients in emergency settings", and "ethnocultural, racial or ethnic minority groups" [Bracken-Roche et al. 2017: 7]. 
As I show in the following section of this article, research ethics is not the only domain where the concept of vulnerability lacks a clear definition; the same is true for philosophy and social sciences.

\section{AMBIGUITY IN THE CONCEPT OF VULNERABILITY}

The concept of vulnerability plays a special role in research contexts within such diverse disciplines like studies on natural disasters, philosophy, bioethics, anthropology, sociology and public health. As Finnish anthropologist Marja-Liisa Honkasalo emphasises, the concept of vulnerability stems from two intellectual traditions [Honkasalo 2018]. On the one hand, the philosophies of Hannah Arendt [1958] and Emmanuel Lévinas [1969, for example], both understand vulnerability as "grounded on relationality". In this tradition vulnerability "refers both to the human condition and to affectability - one's openness to the world" [Honkasalo 2018: 4] $]^{8}$ The other tradition derives from sciences, in particular ecology and geography that study risk, hazards and natural disasters [Honkasalo 2018: 4, Działek and Biernacki 2014, Faas 2016, Rucińska 2014, among others]. Here, vulnerability is understood as "the potential for loss" or "susceptibility to harm" [Faas 2016: 15]. Jarosław Działek and Wojciech Biernacki point out that "in the context of natural hazards vulnerability is usually defined as an ability of the system to predict, deal with, resist and rebuild [the damage] in areas endangered by natural hazards" [2014: 28]. In addition to physical, economic and environmental "conditions of human weaknesses and their creations and surrounding environment of natural disasters" [Działek, Biernacki 2014: 28], social conditions which they describe as "social sensitivity" play a vital role; the latter conditions relate to "the functioning of the social system - individuals, social groups and societies as a whole - when a natural disaster occurs" [Działek, Biernacki 2014: 29]. What spans various research contexts is assumption that certain individuals and social groups require special protection because of their status as vulnerable, either due to natural disasters, or as subjects of human activities and technology.

As philosophers, anthropologists and sociologists point out, vulnerability - especially in neoliberal societies - has negative connotations, being understood as "a risk of or susceptibility to harm" [Coyle, Atkinson 2019: 278], and as "having

8 Bauman [2003: 50-51] seems to lean towards this understanding of vulnerability when he writes about "the sense of common woundability" experienced by the human race in the era of globalisation (Bauman translates the word "vulnerability" into Polish as "ranliwość" ["woundability"]). 
reduced capacity or power to protect one's interests" [Mackenzie 2013:34]. In this sense it is often associated with weakness, dependency, suffering, helplessness and victimisation [Honkasalo 2018, Mackenzie 2013]. Within neoliberal discourse, vulnerability remains "ideologically closely tied to individual responsibility, which again is the central tenet of neoliberal subjectivity" [Honkasalo 2018: 10, also Mackenzie 2013]. Along with other researchers, Honkasalo [2018: 10] points out that, "vulnerability [is a] tool of classification and consequent control and management of the population groups" formerly considered to be "at risk". According to Honkasalo, the technical term "risk" was replaced by a far more effective one, namely, vulnerability. Focusing on elderly care in Finland, this anthropologist illustrates the transformation from the institutional model to informal care at home that is free of charge. From the perspective of the state there are at least two undeniable advantages of vulnerability. First, the language of vulnerability evokes "softness and benevolence" that the "technical language or risk" simply lacks [Honkasalo 2018: 11]. Second, it allows for reduction in governmental expenditures and as such is "economically productive" [Honkasalo 2018: 11].

In public discourse and healthcare and welfare policies the elderly and persons with disabilities or chronic diseases are portrayed as groups considered to be vulnerable and "in need of being spoken for" [Honkasalo 2018: 11]. Importantly, persons classified as belonging to these groups do not "self-define" themselves but are only subjects (or, perhaps, objects) of classification, management and control of biopower. The latter uses the "soft" language of vulnerability in order to "help" and "provide care for" members of such groups, while simultaneously denying them agency [Honkasalo 2018, Mackenzie 2013]. Therefore, the concept of vulnerability is far from neutral. It is criticised mostly for its paternalistic dimension, for being an ally of the technology of social control and - probably most often - for the potentially stigmatising labelling of individuals and groups as vulnerable [Honkasalo 2018, Lange et al. 2013, Mackenzie 2013, Macklin 2003, among others].

As sociologists Bruce Link and Jo Phelan [2001] emphasise in their definition of "stigma", referencing the study on stigma by Erving Goffman [1986 (1963)]",

\footnotetext{
9 Referencing Goffman's work, among others, Maria Świątkiewicz-Mośny [2010, see also Maciejewska-Mroczek et al. 2019] described mechanisms of stigmatising and autostigmatising that Polish women living with Turner syndrome, a rare genetic disease, experienced. The concept of stigma is also used in the analysis of eating, social interactions and experiences of people suffering from phenylketonuria (PKU), a rare metabolic disease in Norway [Diesen et al. 2015]. These two diseases differ in terms of how stigma is manifested. The stigma of TS women is characterised by short height along with a characteristic TS phenotype that has, as Świątkiewicz-Mośny [2010: 10]
} 
"we apply the term stigma when elements of labelling, stereotyping, separation, status loss, and discrimination co-occur in a power situation that allows the components of stigma to unfold" [Link, Phelan 2001: 382].

According to Link and Phelan power plays an indispensable, albeit "taken for granted" role in stigmatising processes. In particular, it refers to the elements the authors describe as a "loss of status" (also understood in terms of health and well-being) and "discrimination". In the context of the latter, which is primarily understood as "structural discrimination", the sociologists claim that it can "produce negative outcomes that have little to do with the stereotyped beliefs that initially motivated the structural discrimination" [Link, Phelan 2001: 379]. Such an understanding of "structural discrimination" approximates it to the "pathogenic vulnerability" [Mackenzie 2013] discussed below. It is worth noting that in their review of the sociological literature, Link and Phelan [2001:364] point out that the concept of stigma is defined in many different ways, which is a result of "the complexity of the stigma phenomenon" [Link, Phelan 2001:365]. This resembles the complexity of vulnerability analysed in this article.

Philosophical and social science discussions have attempted to replace the negative connotations surrounding vulnerability which is understood, as I mentioned above, in relation to "helplessness, neediness and victimhood" and juxtaposed with autonomy [Mackenzie 2013: 38].

For example, Australian philosopher Catriona Mackenzie [2013] does not perceive vulnerability as being in opposition to autonomy, but as an inherent element of autonomy that is grounded in a relational concept of self. As Mackenzie points out, a universalistic approach to vulnerability "ground[s] vulnerability in our corporality" [2013: 38], and, by the same token, makes vulnerability (and dependency) an integral element of the human condition. Such an approach, as the Australian philosopher argues, stands in opposition to labelling, which classifies certain populations or groups "as especially vulnerable and therefore as a target for specific interventions" [Mackenzie 2018: 38]. This labelling is used in discourses pertaining to social politics. Acknowledging universal human vulnerability questions the juxtaposition of "the vulnerable 'others' who must be protected and all other citizens who are represented as somehow invulnerable" [Mackenzie 2018: 38].

emphasises, "features characteristic for both visible and invisible stigma". By contrast, the stigma of people suffering from phenylketonuria is invisible; it is revealed only when they eat [Diesen et al. 2015]. The situation of the majority of patients with other inborn errors of metabolism who participate in our research is similar. 
The grounded analysis of the Mackenzie's theoretical approach to vulnerability is beyond the scope of this article. However, Mackenzie's distinguishing the sources of vulnerability is worth mentioning in the context of research with people suffering from rare diseases. According to her, distinguishing the sources of vulnerability enables comprehensive analysis of vulnerability understood both as an "ontological condition of our humanity", and as "context specific". Thus, alongside the inherent and situational sources of vulnerability, Mackenzie differentiates pathogenic sources, or, simply, speaks of "pathogenic vulnerability". The former constitute an inherent element of the human condition and "arise from our embodiment, our inescapable human needs, and our inevitable dependence on others" [Mackenzie 2013: 39]. The situational sources of vulnerability are context-dependent and influenced by various social-political, economic or environmental factors. Although pathogenic sources are a subset of situational vulnerability, the term itself aims rather at pointing out - among others - how poorly designed social policies may contribute to creating or augmenting social inequalities and injustice [Mackenzie 2013, see also Rogers 2013]. "Paternalistic interventions", writes Mackenzie, "express or perpetuate relationships of domination and inequality among members of a community or between the state and citizens". Therefore, she continues, "they involve a failure to recognize the persons who are the target of such interventions as having the status of autonomous agents" [2013: 56, original emphasis].

It is worth noting that even though in medicine, social services and, as I said above, research ethics, the term vulnerability is used in reference to individuals and particular groups, other studies, like that of Lindsay-Ann Coyle and Sarah Atkinson [2019], extend the application of this term to healthcare systems. Analysing the experiences of people living with "multiple conditions"10 that were treated in one of the care centres in North East England, Coyle and Atkinson observe that vulnerability is attributable to both human subjects and the health system which is unable to correctly diagnose patients suffering from more than one disease. Consequently, their inability to access appropriate care makes them vulnerable ${ }^{11}$. In this context these researchers use the term "structural vulnerabi-

10 The choice of this term was governed by the researchers' attempt to avoid using the overly medicalised term "multiple morbidity". As a practical solution, the researchers adopted the term "multiple conditions" [Coyle, Atkinson 2019: 281]. It is worth noting that each of the research participants suffered from at least one mental health disorder.

11 Another term suggested by Coyle and Atkinson [2019] is "diagnostic vulnerability", which quite accurately captures the experiences of people suffering from rare diseases [see, for example, Timmermans, Buchbinder 2013]. 
lity" to emphasise that vulnerability applies to "the health system, not the specific physicians who practice within its framework" [Coyle, Atkinson 2019: 282, for structural vulnerability and health see also Quesada et al. 2011]. Here, vulnerability is a component of institutional procedures which, while capable of "dealing with" one disease, prove insufficient when there is a need to "deal with" several conditions simultaneously. As the researchers point out, on the one hand "the medical system of practice enacts and enhances this individualised vulnerability" [Coyle, Atkinson 2019: 285]. On the other hand, though, the medical system itself can be "seen as the site of vulnerability" because "normative institutional practice" cannot cope with the ambivalence and multitude of symptoms present in patients suffering from multiple conditions. Sympathetic to other representatives of critical social sciences, Coyle and Atkinson observe that "a dominant conceptualisation of vulnerability constructs a passive body in need of exceptional care and protection owing to incapacity and lack of agency" [2019: 284-285].

To sum up, in philosophy, social sciences and research ethics, the concept of vulnerability is understood in two contrasting ways. On the one hand, it refers to "a universal shared frailty or susceptibility to harm, giving rise to the idea of universal protections for research participants" [Lange et al. 2013:333-334]. On the other, it pertains to particular individuals or groups which are susceptible to specific kinds of hurt or harm more than others [Lange et al. 2013, Rogers 2013]. As I will show in the following, the ambiguity of vulnerability applies to rare diseases. In reference to rare diseases the emphasis is on the "particular" and - as Mackenzie [2013] puts it - "pathogenic" dimension of this concept.

\section{DEFINING RARE DISEASES IN THE EUROPEAN UNION}

There is no single definition for rare diseases globally. In the United States rare diseases are those which "affect small patient populations, typically populations smaller than 200,000 individuals" [Rare Disease Act of 2002]. The number of Americans suffering from such diseases is estimated at 25-30 million. In the first European legal document on rare diseases [Rodwell, Aymé 2015], "Regulation of the European Parliament and of the Council of 1999", a disease is considered rare if it affects no more than 5 persons per 10,000 [Regulation 2000]. This document emphasises that rare diseases "have been identified as a priority area for Community action within the framework for action in the field of public health [Regulation 2000]. 
In their report, Maria Libura and colleagues [2016: 12] underline that the "Council Recommendation on an action in the field of rare diseases" (2009/C 151/02) [Council Recommendation 2009] constitutes "the key legal act" on rare diseases in Europe. This legal document defines rare diseases as having a "low prevalence" (no more than 5 per 10,000 persons in the EU) and, due to the vast number of these diseases, a high total number of people affected. Currently, the number of rare diseases is estimated at $5,000-8,000^{12}$. They are assumed to affect $6-8 \%$ of the population; the total number of such patients in the EU is estimated at 27-36 million [Council Recommendation 2009, EURORDIS 2019]. Moreover, in their recommendations the Council of the EU also points out that "rare diseases are a threat to the health of EU citizens insofar as they are life-threatening or chronically debilitating diseases with a low prevalence and a high level of complexity. Despite their rarity, there are so many different types of rare diseases that millions of people are affected" [Council Recommendation 2009].

According to the same legal document the member states should develop and adopt a plan or strategy which would "aim at guiding and structuring relevant actions in the field of rare diseases within the framework of their health and social systems" [ Council Recommendation 2009]. Such a plan or strategy was to be "elaborate[ed] and adopt[ed]" "preferably by the end of 2013 at the latest"; among the countries we focus on in this research, only Finland adopted a National Plan for Rare Diseases in 2014. Along with Malta, Poland and Sweden are the only member states in the EU which still have not adopted such a national plan or strategy ${ }^{13}$.

12 Approved "orphan drugs" are only available for 4\% of rare diseases [NPRD 2019: 29]. In February 2019, the European Medicines Agency had 149 approved medicines with "orphan drug" status that are devoted to treating rare diseases [NPRD 2019: 29]. According to the available data, in Finland over 100 "orphan drugs" were registered [FIMEA n.d.]; in Sweden 78 "orphan drugs" were reimbursed [Sweden Report 2017], whereas in Poland the number of reimbursed drugs for treating rare diseases amounts to 42 (nearly $60 \%$ of them are drugs for treating various cancers) [NPRD 2019: 29].

13 There is another interesting difference here worth noting - in their NPRD, Finland adopted the same definition for rare disease as the Council Recommendation [2009]. In Sweden, however, to be classified as rare, a disease must affect no more than 1 person per 10,000 combined with a severe lifelong disability [Sweden Report 2017]. Sweden provides an interesting example of a country which has not developed and adopted a national plan or strategy it has nonetheless implemented a range of solutions, such as the 2010 National Focal Point in The Field of Rare Diseases. In 2012, a national plan project was proposed, however, it was not adopted. Our research in Sweden shows that according to both Swedish doctors and representatives of patient organisations such a national plan would be helpful. 


\section{DEFINING PEOPLE WITH RARE DISEASES AS A VULNERABLE GROUP}

This article does not aim at providing a thorough analysis of EU documents, nevertheless it is worth noting that in one of the key European texts on rare diseases, i.e. the Council Recommendation of 8 June 2009 on an action in the field of rare diseases (2009/C 151/02), the adjective vulnerable (in Polish "bezradni"14 ["the helpless"]) appears only once. The term is used at the beginning of the recommendations in the context of the "low prevalence" and "particular isolation" of patients suffering from rare diseases. The document reads as follows, "Most of them suffer from less frequently occurring diseases affecting one in 100,000 people or less. These patients are particularly isolated and vulnerable [Polish: "bezradni"]" [Council Recommendation 2009, emphasis added]. This and similar documents utilise phrases such as "low prevalence", "rarity of these conditions" and "less frequently occurring" as the basic indicators of vulnerability. In this context rare diseases acquire "specificity" and are considered a "unique domain" of public health. This understanding of rare diseases is particularly evident in the following excerpts of the Recommendations: "Because of their low prevalence, their specificity and the high total number of people affected, rare diseases call for a global approach" [article 6, emphasis added] and, "The specificities of rare diseases - a limited number of patients and a scarcity of relevant knowledge and expertise - single them out as a unique domain" [article18, emphasis added]. Charlotte Rodwell and Ségolène Aymé [2015], who analysed policies on rare diseases in Europe, make a similar point. They observe that "the specificities of rare diseases make the area a veritable public health challenge: the limited number of patients and scarcity of knowledge and expertise single rare diseases out as a distinctive domain of high European added-value" [Rodwell, Aymé 2015: 2329, see also Libura et al. 2016].

Similar to research ethics, the Recommendations utilise the labelling approach to classify people suffering from rare diseases as vulnerable. As I will show in the remainder of this article, this also holds true for the Polish project of the National Plan for Rare Diseases [2019]. Patients with such diseases are classified as a group already suffering from diseases that are "life-threatening or caus[e]

14 The Polish translation of the English term "vulnerable" reflects to a much greater extent than the original the links to weakness, dependency and helplessness of people described as vulnerable as a group "in need of being spoken for" [Honkasalo 2018: 11]. Such usage of the term may implicitly encourage paternalistic practices [Mackenzie 2013: 48-49]. I would like to thank an anonymous reviewer who drew my attention to the issue of translation. 
chronic disability" and this alone puts them in a vulnerable position. Although the total number of patients is large, the particular diseases affect very few people. Using Mackenzie's [2013] differentiation between sources of vulnerability, it can be said that inherent sources of vulnerability are foregrounded in the case of people suffering from rare diseases. At the same time, even though those inherent sources are an intrinsic element of the human condition, the embodiment and needs of those patients are not the same as others. Rare diseases differentiate the bodies of the sick from those of the rest of the population [see, for example, Epstein 2007, Hacking 1995] and simultaneously make them the object of interest for research ethics and health policies; this is also indicated by the research conducted in our projects.

In Finland and Sweden, approval from ethics committees to conduct research was dependent on obtaining informed consent from prospective research participants; as I previously mentioned, this is the most common if rather imperfect solution [Lange et al. 2013: 335] to ensure the protection of people classified as vulnerable. Another requirement was to provide a detailed description of what "risks to the health, safety and personal integrity" (in the Swedish version) or the "potentially negative effects and risks" (in the Finnish) the research participants may be exposed to. The Swedish application does not differentiate between clinical and social science research and links the "risk" primarily to its adverse impact on physical or mental health. ${ }^{15}$ In Finland, however, the application acknowledges the ethical principles specific for a given discipline. Thus, in humanities and social and behavioural sciences the "autonomy of research subjects", "avoiding harm", "privacy" and "data protection" are stressed. Additionally, in Finland strong emphasis is put on the "human dignity" of the participants. Interestingly, the term vulnerability is not explicitly used in the application form or any other documents in either of these countries; however, it is implicitly used in both senses mentioned in this article. On the one hand, vulnerability applies to all research participants. On the other, it singles some research participants out - children, patients, the elderly and people with limited capacity to make decisions - as the groups which deserve special protection from researchers.

The project of the Polish National Plan for Rare Diseases [2019] provides a good example of labeling within health policies. This applies specifically to a "rare disease passport" that from the perspective of the sick may be seen as a key policy instrument.

15 For example, one section of the application required a description of "how the method [used in the project] differs from clinical routine or regular treatment". 


\section{A "RARE DISEASE PASSPORT": WRITING VULNERABILITY INTO HEALTHCARE STRATEGIES}

Apart from Malta and Sweden, Poland is the last country in the EU which still has not adopted a national plan or strategy for rare diseases [EURORDIS 2019]. However, unlike Poland, Sweden had already established its first centres of reference for rare diseases as early as in 1990 as well as a registry and information centre for rare diseases in 1999 [Hedley et al. 2016]. Moreover, despite the lack of a national plan, in 2010 the Swedish government established a National Contact Point to coordinate activities in the area of rare diseases. Patients with rare diseases who live in Sweden can rely on the coordinated care of the Karolinska Institute [Sweden Report 2017].

In Poland, the first project of the National Plan for Rare Diseases [hereafter "NPRD" or "Project"] was developed in 2012 by the Team for Rare Diseases at the Ministry of Health; this team also included representatives of patient organizations [Libura et al. 2016: 6; interviews]. The issue of the NPRD has been continuously brought up over the past few years (at least since 2016 when research within our projects began) at conferences and annual events related to Rare Diseases Day. At the conference in Warsaw that took place in November 2019 titled "Rare diseases - diagnostics, medicines and medical devices dedicated to their treatment. Challenges for Poland 2020", a representative from the Ministry of Health admitted that "indeed, the National Plan for Rare Diseases is jinxed". Despite that and similar comments, the overall atmosphere at the conference was rather optimistic; in fact, another team, created in December 2018 by a directive of the Ministry of Health, developed a comprehensive project of the NPRD that was subsequently submitted for public consultations. Despite some sceptical voices, the majority of the conference attendees seemed to believe that the project is the culmination of long-standing efforts.

The latest project of the NPRD - or "strategy", as some of our interlocutors associated with the community of patient organizations emphasised - was published in 2019. It is intended to be implemented by 2025. According to the Ministry of Health website, the NPRD is to be "a tool to provide the continuous execution of health policy tailored to the needs of patients suffering from rare diseases, which will introduce systemic solutions for the health and social problems of that group of patients" [Ministry of Health 2019].

The NPRD project does not mention "prevalence" as a defining feature of rare diseases in Poland; however, it does reference a definition from European documents [e.g., Council Recommendation 2009] according to which "on the EU 
level, rare diseases are defined as those which affect no more than five in 10,000 persons" [NPRD 2019: 18]. The "Polish" definition proposed in the NPRD project focuses not as much on patients, but rather on the diseases themselves. It states that "in Poland, rare diseases are most frequently, but not exclusively defined as genetically determined. Roughly half of the [rare diseases] manifest during childhood; [they are] chronic and often severe and lead to premature death or cause disabilities" [NPRD 2019: 18]. The authors of the project emphasise that in Poland the number of patients suffering from rare diseases oscillates between 2 and 3 million [NPRD 2019: 5] and that "each year over 200,000 new patients are diagnosed with a rare disease" [NPRD 2019: 16].

A detailed analysis of the NPRD project is beyond the scope of this article. I will shortly elaborate on the "Rare Disease Passport" which is one of the key elements of the "integrated care for a person diagnosed with a disease classified as rare" [NPRD 2019: 6] proposed in the Project. First, however, I want to point out that classifying patients on the basis of "low prevalence" - which plays such a crucial role in European definitions - was mirrored in the Project in the context of diagnosis and treatment. The latter document emphasises that "keeping in mind the low number of patients suffering from particular rare diseases, it seems purposeful to centralise the diagnostic and therapeutic processes" [NPRD 2019: 23].

The Authors of the NPRD project perceive the "Rare Disease Passport" (hereafter "Passport") as a "basic care instrument (tool) for a person affected by a rare disease (...), which will facilitate the organisation of information about the disease, aid communication between the patient and the interdisciplinary team (of doctors, teachers, psychologists, physiotherapists) providing care and ensure the optimal coordination of care" [NPRD 2019: 7]. The NPRD enables patients to "acquire" and "exercise their rights" which is what the Passport itself intends [NPRD 2019: 7]. Only doctors from specialised centres and centres of expertise, etc. will be able to issue such passports, which contain sensitive personal data that relate not only to diagnostics and treatment but also to education. In this sense, the Passport is supposed to function as a tool for biomedical classification and bio-political control:

Passports will contain basic information on the patient's health status, the disease(s) and diagnosis, the ORPHA code, the course of treatment, recommendations, the results of check-ups as well as entries about the degree of disability, benefits awarded and educational achievements. Entries in the passport will be made by medical specialists and GPs (...). Similarly, the school inspectorate (or the school at the place of residence of the child's parents) will be required to make entries. These entries will concern the [child's] rights and principles regarding access to the education system which are individually tailored to the needs and abilities of a given child [NPRD 2019: 35-36]. 
The NPRD project was more or less officially criticised by the representatives of patient organizations for being, among others, "too general" and lacking financial solutions [Polityka Zdrowotna 11.07.2019, interviews and informal conversations]. The Passport itself drew particular attention. As a patient organization president expressed "although the very idea of a passport is well-known and great, the way it was formulated in the Plan is quite disturbing. The idea of keeping detailed information about patients there is extremely odd (...); [I found] the idea that the Plan allows third parties such as teachers and welfare services access to highly sensitive data particularly worrisome. Apart from sharing sensitive data erroneous interpretation [of this data] creates further risk" [in Polityka Zdrowotna 11.07.2019].

The NPRD project and biomedical discourse classifies people with rare diseases as a vulnerable population, similarly to the labelling approaches utilised in research ethics. Members of such populations are individuals who "are more likely to suffer from an increased burden of ill health and therefore require extra support or protection" [Rogers 2013: 78]. The Project in fact aims to "enable the patients as well as their caregivers (...) to fulfill social roles and use civilization's advances" [NPRD 2019: 6]. At the same time, the idea of the Passport as one of the key mechanisms utilised to protect and support people suffering from rare diseases acquires the character of "pathogenic vulnerability" [Lange et al. 2013, Mackenzie 2013, Rogers 2013]. Lange and colleagues argue that pathogenic vulnerabilities occur "when social policies aimed at protecting against situational vulnerabilities have the perverse effect of generating new vulnerabilities" [Lange et al. 2013: 336]. As Mackenzie aptly put it, "such forms of so-called protection express relationships of domination and inequality among citizens or between the state and targeted groups of citizens" [2013: 48]. The "objects" of such interventions - not only the patients themselves, but also their families - are subjected to various forms of surveillance that other members of society are not subjected to. Thus, they are denied the "status of autonomous agents, increasing their sense of powerlessness or loss of agency or fuelling resentment and alienation" [Mackenzie 2013: 48-49, original emphasis].

The NPRD project's view of rare diseases and people suffering from them fits very neatly into the labelling concept of vulnerability. Persons with rare diseases are classified as a group which is distinct and susceptible (to an illness, disability etc.) and which becomes the object of bio-political actions carried out by the state and biomedicine. On the one hand, the Project emphasises the autonomy 
of such people ${ }^{16}$, while on the other - by means of making the Passport a key tool of healthcare policy - it denies them the status of autonomous agents and strengthens pathogenic vulnerability.

Here, I want to highlight one issue which was not addressed by the NPRD: research ethics. A detailed account of ethical issues related to "model solutions" for "providing care for" patients suffering from rare diseases exceeds the scope of the project. Nonetheless, the fact that the NPRD ignores them completely is surprising, especially considering that the Project perceives patients and their families as vulnerable on different levels. Understood in this way, the idea of the Passport is paternalistic to the core [Mackenzie 2013: 48]. As Rogers [2013: 83] observes, in research ethics and the ethics of public health, "there is a tendency to label, with the attendant risks of discrimination and paternalism; and there is no comprehensive account of the responsibilities owed to the vulnerable in the way of protections, remedy, compensations, beneficence, or aid." Care for the wellbeing of patients and their families who are perceived as passive overshadows the stigmatising and victimising dimensions of the labelling approach to vulnerability [Honkasalo 2018, Lange et al. 2013, Mackenzie 2013, Macklin 2003, Rogers 2013, among others].

\section{CONCLUSION}

In this article I argue that in philosophy, bioethics and social sciences, the concept of vulnerability is primarily analysed in two ways. First, vulnerability is understood as a universal feature of the human condition. As Rogers [2013: 84] emphasises, "as embodied beings we are all vulnerable in the face of health threats, decreased capacities, and our changing circumstances over time". Second, this concept is applicable to individuals or groups identified as particularly vulnerable and as such in need of special "care" and "protection". In research ethics and public health policy it is this second sense of vulnerability that prevails. As I emphasise in this article, this is also the way people suffering from rare diseases are viewed. For example, in the process of obtaining approval from ethics committees, prospective research participants - here, mostly patients suffering from rare diseases and their families - are identified as a vulnerable group entitled to receive special protection from researchers. Thus, we were required to obtain informed consent from

16 The project emphasises, for example, that people affected by rare diseases and their families have the "right to an independent, self-reliant, non-discriminatory and active life equal to that of all citizens of the Republic of Poland and the EU" [NPRD 2019: 6, emphasis added]. 
all research participants This is the most common solution, which, however, has its limitations, such as "researchers with conflicts of interest" or "dysfunctional institutions" [Lange et al. 2013: 335]. In the context of public health policies, be it at the EU or local level - here the Polish NPRD project - patients suffering from rare diseases are classified as vulnerable primarily through the prism of the "low prevalence" and "specificity" of their diseases. The labelling approach is intended to protect such patients; nonetheless it may lead to paternalistic solutions, such as the aforementioned Passport. Such solutions may lead to stigmatisation and challenge patients' "status of autonomous agents" [Mackenzie 2013: 56, original emphasis]. Acknowledging the concerns of patient organizations would contribute to the development of systemic solutions and would make the Passport much more than merely an instrument of "care for" both patients with rare diseases and their families.

\section{Acknowledgements}

I would like to thank all research participants in Finland, Poland and Sweden as well as the researchers conducting those projects: Anna Chowaniec, dr hab. Anna Kwaśniewska, prof. UG, Jan Frydrych, Katarzyna E. Król and dr Filip Rogalski. I would also like to thank the organizers and participants of the thematic group "Ethical aspects in social research" at the $17^{\text {th }}$ Polish Sociological Congress in Wroclaw. Finally, I am grateful to the editors of Przeglad Socjologiczny and anonymous reviewers for their constructive comments on the original Polish version of this article.

\section{BIBLIGRAPHY}

Arendt Hannah. 1958. The human condition. Chicago: University of Chicago Press.

Bauman Zygmunt. 2003. „Żyjąc (czasami umierając) na tłocznej planecie”. Przegląd Socjologiczny 52(2): 35-51.

Bracken-Roche Dearbhail, Emily Bell, Mary Ellen Macdonald, Eric Racine. 2017. "The concept of 'vulnerability' in research ethics: An in-depth analysis of policies and guidelines". Health Research Policy and Systems 15(8): 1-18.

Chowaniec-Rylke Anna. 2018. „Posiłek co dwie godziny, czyli o relacjach rodzinnych, 'zarządzaniu' dietą i definicjach niepełnosprawności w przypadku rzadkiej choroby metabolicznej”. Etnografia Polska 62(1-2): 163-182.

Council Recommendation 2009. Council Recommendation of 8 June 2009 on an action in the field of rare diseases (2009/C 151/02) https://eur-lex.europa.eu/legal-content/EN/TXT/ HTML/?uri=OJ:C:2009:151:FULL\&from=DE [access: 15.09.2020]. 
Coyle Lindsay-Ann, Sarah Atkinson. 2019. "Vulnerability as practice in diagnosing multiple conditions". Medical Humanities 45: 278-286.

Diesen Plata Sofie, Ingrid Wiig, Lisbet Grut, Bengt Frode Kase. 2015. "Betwixt and between being healthy and ill: the stigma experienced by young adults with phenylketonuria". Scandinavian Journal of Disability Research 17(4): 321-334.

Działek Jarosław, Wojciech Biernacki. 2014. „Wrażliwość społeczna na klęski żywiołowe - ujęcia teoretyczne i praktyka badawcza". Prace i Studia Geograficzne 55: 25-39.

Ehmke vel Emczyńska-Seliga Ewa. 2016. „Zaburzenia odżywiania u pacjentów z rzadkimi chorobami metabolicznymi”. Wspótczesna dietetyka 6: 48-53.

Epstein Steven. 2007. Inclusion. The politics of difference in medical research. Chicago: The University of Chicago Press.

EURORDIS. 2019. Europlan National Conferences. EURORDIS - Rare Diseases Europe. https://www.eurordis.org/content/europlan-national-conferences [Last accessed 9.02.2020]

Faas A.J. 2016. "Disaster vulnerability in anthropological perspective". Annals of Anthropological Practice 40(1): 14-27.

FIMEA. n.d. Orphan drugs. FIMEA/Finnish Medicines Agency. https:/www.fimea.fi/web/ en/marketing_authorisations/marketing_authorisation_application/orphan-drugs [access: 16.02.2020].

Finland Report. 2017. State of the art for rare diseases - activities in EU member states and other European countries. Finland report. Electronic document.

Goffman Erving. 1986 [1963]. Stigma. Notes on the management of spoiled identity. New York: A Touchstone Book. Published by Simon \& Schuster Inc.

Hacking Ian. 1995 Making Up People. In: Reconstructing individualism, T.L. Heller, M. Sosna, D.E. Wellbery (eds.), 161-171. Stanford, CA: Stanford University Press.

Hedley Victoria, Helen Murray, Charlotte Rodwell, Ségolène Aymé. 2016. Overview report on the state diseases in Europe. http://www.rd-action.eu/wp-content/uploads/2017/08/ Overview-Report-State-of-the-Art-2016-Final-for-Portal.pdf [access: 26.02.2020].

Honkasalo Marja-Liisa. 2019. "Guest editor's introduction: Vulnerability and inquiring into relationality”. Suomen Antropologi: Journal of the Finnish Anthropological Society 43(3): 1-21.

Kleinman Arthur. 1989. The illness narratives. Suffering, healing, and the human condition. Basic Books.

Lange Margaret Meek, Wendy Rogers, Susan Dodds. 2013. "Vulnerability in research ethics: A way forward". Bioethics 27(6): 333-340.

Lévinas Emmanuel. 1969. Totality and infinity. An essay on exteriority. Pittsburgh: Duquesne University Press.

Libura Maria, Magdalena Władusiuk, Monika Małowicka, Edyta Grabowska, Małgorzata Galązka-Sobotka, Jerzy Gryglewicz. 2016. Choroby rzadkie w Polsce. Stan obecny i prespektywy. Warszawa: Uczelnia Lazarskiego.

Link Bruce G, Jo C. Phelan. 2001. "Conceptualizing stigma". Annual Review of Sociology 27: 263-85.

Maciejewska-Mroczek Ewa, Magdalena Radkowska-Walkowicz, Maria Reimann (ed.). 2019. Zespót Turnera. Głosy i doświadczenia. Warszawa: Oficyna Naukowa.

Mackenzie Catriona. 2013. The importance of relational autonomy and capabilities for an ethics of vulnerability. In: Vulnerability: New essays in ethics and feminist philosophy, C. Mackenzie, W. Rogers, S. Dodds (eds.), 34-59. Oxford: Oxford University Press.

Macklin Ruth. 2003. "Bioethics, vulnerability, and protection". Bioethics 17(5-6): 472-486. 
NPRD. 2019. National Program for Rare Diseases: A Project [Narodowy Plan dla Chorób Rzadkich: Projekt]. 10.06.2019. https://www.gov.pl/web/zdrowie/projekt-uchwaly-radyministrow-ws-przyjecia-narodowego-planu-dla-chorob-rzadkich [access: 26.02.2020].

Oltarzewski Mariusz. 2018. „Badania przesiewowe noworodków w Polsce, 2018 rok”. Postepy Neonatologii 24(2): 111-122.

Paul Diane B., Jeffrey P. Brosco. 2013. The PKU paradox. A short history of genetic disease. Baltimore: Johns Hopkins University Press.

Polityka Zdrowotna. 11.07.2019. Choroby rzadkie: Narodowy plan konsultowany bez pacjentów? https://www.politykazdrowotna.com/47070, choroby-rzadkie-narodowy-plankonsultowany-bez-pacjentow [access: 16.01.2020]

Quesada James, Laurie Kain Hart, Philippe Bourgois. 2011. "Structural vulnerability and health: Latino migrant laboreres in the United States". Medical Anthropology 30(4): 339-362.

Rajtar Malgorzata. 2019. "Normalised eating and dietary guidelines in LCHAD deficiency". Ethnologia Polona 40: 91-108.

Rajtar Małgorzata. 2017. „O (nie)naturalności jedzenia. Pokarmy i technologie biomedyczne w chorobach metabolicznych". Lud 101: 379-396.

Rare Diseases Act of 2002. 2002. Public Law 107-280, 6. November 2002. https://history.nih. gov/research/downloads/PL107-280.pdf [access: 20.01.2020].

Regulation 2000. Regulation (EC) No 141/2000 of the European Parliament and of the Council of 16 December 1999 on orphan medicinal products. https://eur-lex.europa.eu/legal-content/ $\mathrm{EN} / \mathrm{TXT} / \mathrm{PDF} /$ ?uri=CELEX:32000R0141\&from=EN [access: 15.09.2020].

Rodwell Charlotte, Ségolène Aymé. 2015. "Rare disease policies to improve care for patients in Europe". Biochimica et Biophysica Acta 1852: 2329-2335.

Rogers Wendy. 2013. Vulnerability and bioethics. In: Vulnerability: New essays in ethics and feminist philosophy, C. Mackenzie, W. Rogers, S. Dodds (eds.), 61-87. Oxford: Oxford University Press.

Różyńska Joanna. 2016. „Etyka i ryzyko w 'nieterapeutycznych' badaniach biomedycznych”. Przeglad Filozoficzny. Nowa Seria 2(98): 213-226.

Rucińska Dorota. 2014. „Podatność społeczna na zagrożenia naturalne jako element ryzyka. Przegląd koncepcji naukowych”. Prace i Studia Geograficzne 55: 133-144.

Sweden Report. 2017. State of the art of rare disease - Activities in EU member states and other European countries. Sweden report http://www.rd-action.eu/wp-content/uploads/2017/10/ Sweden-Report-09.10.2017.pdf [access: 26.02.2020].

Światkiewicz-Mośny Maria. 2010. Tożsamość napiętnowana. Socjologiczne studium mechanizmów stygmatyzacji i autostygmatyzacji na przykładzie kobiet z Zespołem Turnera. Kraków: NOMOS.

Świerkosz Monika. 2018. „Ciała podatne na zranienie. Judith Butler, samozniszczenie i radykalne akty oporu". Etyka 57: 69-86.

The Belmont Report. 1979. The Belmont Report: Ethical principles and guidelines for the protection of human subjects of research. The National Commission for the Protection of Human Subjects of Biomedical and Behavioral Research. https://www.hhs.gov/ohrp/sites/default/files/the-belmont-report-508c_FINAL.pdf [access: 20.01.2020].

Timmermans Stefan, Mara Buchbinder. 2013. Saving babies? The consequences of newborn genetic screening. Chicago: The University of Chicago Press.

Van der Lippe Charlotte, Plata S. Diesen, Kristin B. Feragen. 2017. "Living with a rare disorder: A systematic review of the qualitative literature". Molecular Genetics \& Genomic Medicine 5(6): 758-773. 
Matgorzata Rajtar

\section{KONCEPCJA VULNERABILITY A ETYKA BADAWCZA I POLITYKI ZDROWOTNE W KONTEKŚCIE CHORÓB RZADKICH}

\section{Streszczenie}

Od lat 90. XX wieku choroby rzadkie zaczęły zyskiwać specjalny status w polityce zdrowotnej Unii Europejskiej (UE). Zgodnie z kluczowymi aktami prawnymi UE pacjenci cierpiący na choroby rzadkie powinni mieć prawo do dobrej jakości leczenia, tak samo jak i inni pacjenci. „Niska częstość występowania" każdej z chorób rzadkich, a jednocześnie duża liczba chorych nimi dotkniętych (szacuje się, że jest to około 27-36 milionów osób w UE) sprawiają, że osoby należące do tej grupy uznaje się jako szczególny sposób vulnerable.

W niniejszym artykule analizuję rzadko poruszane w piśmiennictwie z zakresu nauk społecznych i humanistycznych kwestie etyczne związane z klasyfikowaniem osób z chorobami rzadkimi jako grupy określanej mianem vulnerable. Argumentuję, odwołując się do literatury, że w etyce badawczej oraz etyce i polityce zdrowia publicznego dominuje negatywne i etykietyzujące rozumienie vulnerability, w ramach którego pewne jednostki, grupy lub populacje są klasyfikowane jako podatne na większe ryzyko szkody czy zranienia niż inne i w związku z tym wymagają szczególnej ochrony, czy to ze strony prowadzących badania, czy na przykład systemu opieki zdrowotnej. Takie rozumienie niesie ze sobą niebezpieczeństwo praktyk paternalistycznych i ,patogennej vulnerability" [Mackenzie 2013] oraz może przyczynić się do procesów dyskryminacji, stygmatyzacji i wiktymizacji. Jak pokazuję w artykule, polityki zdrowotne odnoszące się do chorób rzadkich przyczyniają się często do zwiększenia ,patogennej vulnerability”.

Słowa kluczowe: vulnerability, etyka badawcza, choroby rzadkie, etnografia, polityki zdrowotne 